\title{
THE SYSTEMIC APPROACH TO NATIONAL INNOVATION SYSTEMS IN A KNOWLEDGE-BASED ECONOMY
}

\author{
Ioan Moise Achim ${ }^{1}$ \\ Teodora Popescu ${ }^{2}$
}

\begin{abstract}
The aim of this paper is to present the concept of National Innovation Systems, their history and role in the understanding of a systemic approach to research, development and innovation at national and global level. We will present a brief introduction to the main operational concepts and the history of the concept, from its beginnings to the present times.
\end{abstract}

Key words: National Innovation Systems, knowledge-based economy;

JEL codes: O31, O32, O43.

\section{Introduction}

In a Europe of knowledge and a world of information, the importance of research and innovation cannot be underestimated. Decisions regarding these two crucial elements of growth and development are therefore paramount to all stakeholders (decision makers, industry, academia, interest groups etc.). They transcend the individual or company level at which research and innovation primarily occur, having multiplied effects at local, regional, national and international scale.

In March 2000, the European Council gathered in Lisbon and set out the "Lisbon Strategy" an action and development plan aimed at turning the European Union (EU) into the most competitive economy in the world and achieving full employment by 2010. This strategy, developed at subsequent meetings of the European Council, is based on three pillars:

- An economic pillar preparing the ground for the transition to a competitive, dynamic, knowledge-based economy. In this context, great importance is laid on the need to constantly adapt to changes in the information society and to encourage research and development.

- A social pillar designed to modernise the European social model by investing in human resources and combating social exclusion. To this end, the Member States have to invest in education and training, and to carry out an active policy for employment, thus facilitating the move to a knowledge economy.

- An environmental pillar, which was subsequently added at the Gothenburg European Council meeting in June 2001, draws attention to the fact that economic growth must be decoupled from the use of natural resources. [ http://europa.eu/scadplus/glossary/lisbon_strategy_en.htm]

As a follow-up, a list of targets has been drawn up with a view to attaining the goals set in 2000. Considering that the above-mentioned actions fall almost exclusively within the sphere of competence of the Member States, an open method of coordination (OMC) necessitating the development of national action plans has been introduced. In the Conclusions of the Presidency, it was said that the European Union set as new strategic goal "to become the most competitive and dynamic knowledge-based economy in the world capable of sustainable economic growth with more and better jobs and greater social cohesion. Achieving this goal requires an overall strategy aimed at:

\footnotetext{
1 “1 Decembrie 1918” University, No.5, Gabriel Bethlen, achimmoise@yahoo.com

2 “1 Decembrie 1918” University, No.5, Gabriel Bethlen, teo_popescu@hotmail.com
} 
- preparing the transition to a knowledge-based economy and society by better policies for the information society and $\mathbf{R} \boldsymbol{\&} \mathbf{D}$, as well as by stepping up the process of structural reform for competitiveness and innovation and by completing the internal market;

- modernising the European social model, investing in people and combating social exclusion;

- sustaining the healthy economic outlook and favourable growth prospects by applying an appropriate macro-economic policy mix." [ http://www.europarl.europa.eu/summits/lis1_en.htm Lisbon European Council 23 and 24 March 2000 Presidency Conclusions]

As far as the strategy is concerned, it was stated that it was created to "enable the Union to regain the conditions for full employment, and to strengthen regional cohesion in the European Union." The European Council saw the need "to set a goal for full employment in Europe in an emerging new society which is more adapted to the personal choices of women and men. If the measures set out below are implemented against a sound macro-economic background, an average economic growth rate of around $3 \%$ should be a realistic prospect for the coming years." The means through which the strategy could be implemented were also taken into consideration - and here was the role of the OMC emphasised: "improving the existing processes, introducing a new open method of coordination at all levels, coupled with a stronger guiding and coordinating role for the European Council to ensure more coherent strategic direction and effective monitoring of progress." This method entails establishing specific guidelines and timetables to attain the short, medium and long term goals set by the Member States; quantitative and qualitative indicators and benchmarks to compare with 'the best in the world' and adjusted to the needs of various Member States and sectors in order to assimilate best practice; converting these guidelines into policies, with achievable targets and measures, allowing for national and regional differences; and last but not least, carrying out regular monitoring, evaluation and peer review meant as interactive and participatory learning processes.

Acting upon these recommendations, European Research Ministers in their Council Resolution adopted on 15 June 2000, asked the Commission, in cooperation with the Member States, to produce a full set of indicators and a methodology for benchmarking the following themes: - Human resources in RTD (Research, Technology and Development), including attractiveness of science and technology professions,

- Public and private investment in RTD,

- Scientific and technological productivity,

- Impact of RTD on economic competitiveness and employment,

- Public understanding of science and technology.

This represented in fact the first time that a benchmarking exercise in the area of RTD policies had been launched at EU level.

\section{Research and Innovation}

According to the Frascati Manual. Proposed standard practice for surveys on research and experimental development (2002), Paris: OECD (p.30), R\&D represents "creative work undertaken on a systematic basis in order to increase the stock of knowledge, including knowledge of man, culture and society, and the use of this stock of knowledge to devise new applications". It comprises three broad activities: a) basic research (experimental or theoretical work carried out in order to acquire new knowledge of the underlying foundation of phenomena and observable facts, without any particular application or use); b) applied research (original investigation performed with a view to acquiring new knowledge, but unlike basic research, it has a specific practical aim or objective); c) experimental research (systematic work, using existing knowledge obtained from research and/or practical experience, which is aimed at producing new materials, products or devices, to installing new processes, systems and services, or to improving those already produced or in use). R\&D encompasses both formal R\&D in R\&D units and informal or occasional R\&D in other units. 
According to The Oslo Manual. Guidelines for Collecting and Interpreting Innovation data (2002, p. 46), innovation represents the "implementation of a new or significantly improved product (good or service), or process, a new marketing method, or a new organisational method in business practices, workplace organisation or external relations" [ Oslo manual. Guidelines for collecting and interpreting Innovation data. $3^{\text {rd }}$ ed. Paris: OECD and EUROSTAT (2005) Organisation for economic co-operation and development. Statistical office of the European communities. OECD 2005]. The same document lists four types of innovation: a) product innovation (the introduction of a good or service that is new or significantly improved with respect to its characteristics or intended uses, including relevant improvements in technical specifications, components and materials, incorporated software, user friendliness or other functional characteristics); b) process innovation is the implementation of a new or greatly improved production or delivery method, including important changes in techniques, equipment and/or software); c) marketing innovation (the implementation of a new marketing method encompassing important changes in product design or packaging, product placement, product promotion or pricing) and d) organisational innovation (the implementation of a new organisational method in the company's business practices, workplace organisation or external relations).

Traditionally, the analysis of innovative and economic performance is focused on the 'inputs' (e.g. research expenditures) and the 'outputs' (e.g. patents). Over time, the limitations of these traditional methods had become evident and "their ability of measuring general innovativeness of an economy is small" (OECD, 1997, p. 9). This approach lacks an explanation that justifies the trends in innovation, growth and productivity and neglects to analyse how the actors interact in the innovation process.

It is important in the following to explain concept of 'national innovation systems' (NIS), by which we broadly understand a network of stakeholders who have a vested interest in creating, developing and promoting science and technology outputs. The interactions among the various stakeholders involved are of key importance in translating these 'inputs' and 'outputs' and the study of this web of interactions is a direct concern of NIS.

There is not single, widely-accepted definition for NIS. The following are some common definitions (OECD, 1997, p. 10) of the above concept:

".. the network of institutions in the public and private sectors whose activities and interactions initiate, import, modify and diffuse new technologies." (Freeman, 1987)

".. the elements and relationships which interact in the production, diffusion and use of new, and economically useful, knowledge ... and are either located within or rooted inside the borders of a nation state." (Lundvall, 1992)

"... a set of institutions whose interactions determine the innovative performance ... of national firms.” (Nelson, 1993)

".. the national institutions, their incentive structures and their competencies, that determine the rate and direction of technological learning (or the volume and composition of change generating activities) in a country." (Patel and Pavitt, 1994)

".. that set of distinct institutions which jointly and individually contribute to the development and diffusion of new technologies and which provides the framework within which governments form and implement policies to influence the innovation process. As such it is a system of interconnected institutions to create, store and transfer the knowledge, skills and artefacts which define new technologies." (Metcalfe, 1995)

A brief history of the NIS notion is provided by professor Bengt-Åke Lundvall, in a working paper (Lundvall, 2007) produced by ITPS (Swedish Institute for Growth Policy Studies) in 2007. Lundvall posits that the ideas encompassed by this concept were first to be found in the works of 
Friedrich List (1841), whose interpretation of 'national systems of production' paid heed to a wide set of national institutions including those operating in education and training as well as infrastructures such as networks for transportation of people and commodities. He put more emphasis on the development of productive forces rather than on allocation issues. From his position of a German catch-up economist he was disapproving of the 'cosmopolitan' approach of Adam Smith (1776), where free trade was assumed to be to the appanage of both Germany (the laggard) and England (the lead economy).

As far as the 'national production system' was concerned, List called attention to the necessity for the state to build national infrastructure and institutions with a view to promoting the accumulation of 'mental capital' and use it to stimulate economic development rather than just to sit back and rely on 'the invisible hand' to manage all problems.

The next to address the issue of the 'national system of innovation' was Christopher Freeman in a paper he wrote in 1982 (but only published in 2004) for the Organisation for Economic Co-operation and Development (OECD) expert group on Science, Technology and Competitiveness, with the title "Technological infrastructure and international competitiveness". Freeman (2004) too stressed the usefulness of government involvement in promoting the development of a technological infrastructure. He also underlined the limited relevance of shortterm competitiveness strategies such as manipulating national wage and currency rates. One of the tenets of Freeman's theory is that, if we want to understand why and how world economic supremacy moves from one country to another, we need to look at how new technological systems come to the fore and how they fit in or clash with the existing national patterns of institutions. It may well be possible that some countries, prospering in the context of one technological system may fall prey to their own success since they will have great difficulties in adapting their institutional apparatus to the new technological system.

Starting with the ' 80 's, the necessity of a national system of innovations began to gain ground among several economists concerned with innovation research. Dick Nelson and other American scholars had compared technology policy and institutions in the high technology field in the US with similar patterns in Japan and Europe. The Science and Technology Policy Research at Sussex University carried out several studies comparing industrial development in Germany and the UK examining for instance differences in the management of innovation, work practices and engineering education.

The modern version of the full concept 'national innovation system' came to life in specialist literature in 1987, in Christopher Freeman's book on innovation in Japan. In his work he made a thorough analysis of both 'intra' and 'inter' organizational characteristics of firms, corporate governance, the education system as well as the role of government (Freeman, 1987). Freeman's cooperation with Nelson and Lundvall on a major International Federation of Institutes for Advanced Study project on technical change and economic theory resulted in a book with a section with chapters on 'national systems of innovation'.

Another contribution that is worth mentioning in this context is the one made by Michael Porter (1990) on the competitive advantage of nations. Although there is no explicit reference to the concept of innovation system as such, there is nevertheless, significant interrelation with the ideas propounded in the above-mentioned works. His emphasis on feedback mechanisms from and interaction with domestic suppliers and users as a factor that gives competitive advantage is especially noteworthy.

As far as different approaches to delineate the constituent elements of an innovation system, we need to emphasise the fact that different scholars have different conceptions. The presentation of various definitions, as made by Lundvall in the above-mentioned paper, might nonetheless prove useful for the purpose of our study.

Lundvall (2007, p. 12) contends that one of the main common underlying premises is that national systems differ in terms of specialization in production, trade and knowledge. This is in fact 
not a new idea, since neoclassical trade theory starts from a similar assumption. Still, the difference lies in that among NIS-analysts it is assumed that there exists a dynamic co-evolution between what countries specialize in doing and what people and firms in these countries know how to do well. The implications are that, on the one hand, both the production structure and the knowledge structure will change only slowly and, on the other, that such change must involve learning. The fact that the trade specialisation does not imply a comparative advantage engenders a debate on what kind of specialisation might be most favourable to generate economic prosperity.

Secondly, Lundvall (2007, p. 12) maintains that elements of knowledge that bear relevance to economic performance tend to be localized and therefore cannot be easily transferred from one place/context to another. NIS are necessary exactly because we live in a society where knowledge does not equal information, and people do not all have unlimited access to information.

Thirdly, as a follow-up to the previous assumption, he upholds that knowledge, which represents something more than information, encompasses tacit elements as well. It may be contended that significant elements of knowledge are intertwined in the minds and bodies of agents or anchored in routines of companies and not least in relationships between people and organizations. This hypothesis is construed along the line of a similar contention that innovation system approaches transcend the precept of methodological individualism (Lundvall, 2007, p. 13).

Fourthly, if we are to grasp the process of innovation, we have to concentrate on interaction and relationships, as companies, knowledge institutions and individuals very rarely innovate on their own, innovation being in fact a corollary of the multiplying processes of interactive learning and searching. Therefore, this entails that the system needs to be addressed concurrently from both the point of view of its constituent elements and that of the relationships established between the afore-mentioned elements. Consequently, it can safely be predicated that the innovation system approach is entirely 'interactionist' (Lundvall, 2007, p. 13).

NIS have captured increased analytical consensus because they recognise the importance of knowledge flows,; there is a increased usage of systems approaches and the knowledge institutions are greater than ever in number. The knowledge embodied in human beings, known as 'human capital' or 'tacit knowledge' is also being recognised as of key importance to economic growth. The remaining 'codified knowledge' resides in publications, patents and an increasing number of sources cultivated by the information technology diffusion. Innovation is considered as the result of the complex interaction between various stakeholders, including those within the system's feedback loops.

An understanding of NIS helps identify leverage points and pinpoint mismatches that Government policies need to address so as to boost the overall innovation performance and competitiveness of a nation. The measurement and assessment of core knowledge flows is centred on:

1. Industry Interactions e.g. joint research activities and technical collaborations, such as the Co-operative Agreements and Technology Indicators database of the Maastricht Economic Research Institute on Innovation and Technology.

2. Public/Private Interactions among enterprises, academia and research institutes e.g. co-research, co-patenting, co-publications, citation analysis, exchange programs and firm surveys.

3. Knowledge Distribution Power of and technology e.g. technology, use of advanced machinery and equipment adoption rates.

4. Personnel mobility e.g. movements of skilled personnel to and fro various enterprises and institutions (OECD, 1997, pp. 7-18).

Countries tend to evolve along technological paths, know as 'trajectories', dependent of past, present and future patterns of knowledge accumulation that usually are country specific. Generally speaking some countries are not in a position to diffuse technology across a whole range of industries, but "in clusters of industries connected through vertical and horizontal relationships" (Porter, 1990). Different clusters have varying knowledge patterns dependent of the country specific 
context. A densely knitted knowledge network amongst forestry firms in Finland gave this specific cluster a strong national economic position and a competitive edge internationally.

"The quality of public research infrastructure and its links to industry may be one of the most important national assets for supporting innovation. Government supported research institutes are main performers of generic research and produce not only a body of basic knowledge for industry, but are also sources of new methods, instrumentation and valuable skills" (OECD, 1997, p. 9). The firms that have access to outside knowledge, by linking to knowledge networks and which are capable of adapting this knowledge to their needs are considered as the most innovative firms. Some Nordic studies (Smith et al, 1995; Stenberg et al, 1996) have proved that higher levels of qualified personnel mobility contributed positively to both the overall labour force skills level and to the economic innovative performance. Other NIS studies, in countries like Germany, have shown that technical collaboration, technology diffusion and personnel mobility have improved the innovative capacity in most sectors.

There are different ways of analysing NIS (OECD, 1997, pp. 7-8, 21):

1. Firm-level innovation surveys that question and rank innovation sources e.g. the Community Innovation Survey (CIS) and Policies, Appropriability and Competitiveness for European Enterprises Project.

2. Cluster analysis e.g. sectoral analysis.

3. Differing levels e.g. international, pan-regional, national and sub-regional.

The national level continues to be the most important, due to nation-specific, domestic interactions but at the same time the importance of a more open NIS concept is being acknowledged. International knowledge indictors are relatively advanced and in general increasing in most countries although with varying levels and pace. The United States and Europe remain the largest net exporter and the largest net importer of "know-how" (OECD, 1997, p. 29). The importance of R\&I has gained ground at all levels of the economy and governments have directed their intervention on domestic market failures through R\&I tax credits and subsidies (OECD, 1997, p. 41).

These instruments need to be complemented with new policies targeted at increasing the networking and absorptive capacities of domestic firms. Firms need to invest internally in R\&I, personnel training and ICT to identify sector specific innovations and technologies that can be blended or adapted according to the firms' needs. Statistical indicators that are capable of measuring knowledge distributions and interactions between stakeholders are still not as robust as conventional indictors mainly due to a lack of specific datasets. The ultimate goal is to establish a link between NIS and economic performance in a way that countries can be made comparable across different sectors (OECD, 1997, p. 41-46).

\section{Conclusions}

The above analysis of NIS leads us to analyse the R\&D strategies of various firms that act within a wider-ranging institutional framework in order to coordinate and streamline the various actions they undertake to stay competitive and increase market share. We also have to pay heed to the fact that besides the institutional context in which they act, firms may embark upon courses of action other than just $\mathrm{R} \& \mathrm{D}$, such as getting information and/or accessing knowledge with respect to their production or their markets, or activities entailed by the process of outsourcing the research outputs, by ensuring an active interface between users and producers of R\&D.

Therefore, it is clear nowadays more than ever, that in economies which increasingly become knowledge-based, the range of activities taken into consideration with respect to the R\&D processes is constantly expanding. Besides outsourcing, R\&D development can be engendered in the shape of cooperation, seen as separate from outsourcing. We have witnessed over the last years the creation of many strategic alliances, most of them technology-oriented (sharing some R\&D, 
developing common standards, etc.). Such alliances were in general made between multinationals, which adds a transnational dimension to the process.

Some other aspects that are especially noteworthy with reference to the efforts carried out by different firms to enhance R\&D outputs, are obviously the activities towards assessing the direction of markets or the need of users in order to innovate and develop their market share, or activities geared at developing a qualified labour force, whose skills and knowledge may be attuned to the new needs and new scientific breakthroughs.

Bearing in mind all the above, it is therefore obvious why there was this need for a systemic approach to R\&D in knowledge-based economy. Nevertheless, it has to be noted that the knowledge and innovation systems of countries display visible differences that arise in conjunction with their individual paths of specialisation in production. Consequently, it is important to study the weaknesses which are most pivotal for national economic growth and development, and not necessarily apply a policy which proved successful in the case of another country.

\section{References:}

1. Caracostas, P. \& Muldur, U. 1997, Society, The Endless Frontier: A European vision of research and innovation in the 21 st century. Brussels: Office for Official Publications of the EC;

2. Freeman, C., 1987, Technology policy and economic performance: Lessons from Japan. London: Pinter Publishers. Cited in Lundvall, B.-Å. (2007). National Innovation System: Analytical Focusing Device and Policy Learning Tool. Working paper, R2007:004. Östersund: ITPS Swedish Institute for Growth Policy Studies;

3. Lundvall, B.-Å., 2007, National Innovation System: Analytical Focusing Device and Policy Learning Tool. Working paper, R2007:004. Östersund: ITPS Swedish Institute for Growth Policy Studies;

4. Lundvall, B-A., \& Borrás, S., 1997, The Globalising Learning Economy: Implications for Innovation Policy (Draft report based on the preliminary conclusions from several projects under the TSER Programme, DG XII, Commission of the European Union). Luxembourg: Office of Official Publications of the European Communities;

5. Luwel, M., 2004, The Use of Input Data in the Performance Analysis of R\&D Systems: Potentialities and Pitfalls. In H. F. Moed, W. Glänzel \& U. Schmoch (Eds). Handbook of Quantitative Science and Technology Research. (pp. 315-338). Dordrecht: Kluwer;

6. Malerba, Franco et al., 1996, "Industry Studies of Innovation Using CIS Data: Computer and Office Machinery", paper prepared for the Eurostat Conference on Innovation Measurement and Policies, May;

7. MERIT (1995), PACE Report: Innovation Strategies of Europe's Largest Industrial Firms, Luxembourg;

8. Metcalfe, S., 1995, "The Economic Foundations of Technology Policy: Equilibrium and Evolutionary Perspectives", in P. Stoneman (ed.), Handbook of the Economics of Innovation and Technological Change, Blackwell Publishers, Oxford (UK)/Cambridge (US);

9. Nelson, R. (ed.), 1993, National Innovation Systems. A Comparative Analysis, Oxford University Press, New York/Oxford. 